\title{
Box Tree Moth (Cydalima perspectalis, Lepidoptera; Crambidae), New Invasive Insect Pest in Croatia
}

\author{
Dinka Matošević1 ${ }^{1 飞}$
}

${ }^{1}$ Croatian Forest Research Institute, Cvjetno naselje 41, 10450 Jastrebarsko, Croatia

Corresponding author: e-mail: dinkam@sumins.hr

Citation:

MATOŠEVIĆ D 2013 Box Tree Moth (Cydalima perspectalis, Lepidoptera; Crambidae), New Invasive Insect Pest in Croatia. South-East Eur For 4 (2): 89-94

\begin{abstract}
Background and purpose: Alien invasive species have been described as an outstanding global problem. Hundreds of species are intentionally and unintentionally moved worldwide and and numbers of introductions to new habitats have been accelerated all over the world due to the increasing mobility of people and goods over the past decades. Numerous alien insect species, many of them introduced only in the last 20 years, have become successfully established in various ecosystems in Croatia. Box tree moth (Cydalima perspectalis, Lepidoptera; Crambidae) is an invasive pest recently introduced to Europe causing serious damage to ornamental box (Buxus sp.) shrubs and trees. The aim of this paper is to describe the biology of box tree moth with prognosis of its future spread and damages in Croatia.

Material and methods: Young larvae (first and second larval stage) and adults of box tree moth were collected in August and September 2013 in Arboretum Opeka and in Varaždin. They were brought to the entomological laboratory of Croatian Forest Research Institute where they were reared to pupae and then to moths.

Results and Conclusions: The box tree moth was recorded for the first time in North Croatia in August 2013. Larvae were found defoliating box plants (B. sempervirens) in Arboretum Opeka, Vinica and they have been identified as $C$. prespectalis. According to damages it can be assumed that the pest has been introduced to the region earlier (in 2011 or 2012) and that the primary infection has not been detected. At least two generations per year could be assumed in Croatia in 2013. The damage done to box tree plants on the locality of study is serious. The plants have been defoliated, particularly in the lower parts. The defoliation reduced the amenity value of plants. This is the first record of this pest and its damages in Northern Croatia and it can be expected that the pest will rapidly spread to other parts of Croatia seriously damaging box plants, becoming threat to gardens and parks in Croatia.
\end{abstract}

Keywords: invasive species, damage, defoliation, biology of Box tree moth

\section{INTRODUCTION}

Alien species are considered as one of the major threats to biodiversity after habitat destruction $[1,2]$ causing enormous damage to ecosystems and economies [2, 3, 4]. As a result, they have been described as an outstanding global problem [5]. Alien species can significantly 
impact the functional properties of ecosystems, disrupt food webs, displace indigenous species, even threaten food and water supplies [6]. Hundreds of species are intentionally and unintentionally moved worldwide [7] and these introductions have been accelerated all over the world due to the increasing mobility of people and goods over the past decades [8] with varied modes of entry and transportation routes [9]. Numerous alien insect species, many introduced only in the last 20 years, have become successfully established in various ecosystems in Croatia [10].

While a certain number of alien insect species have little impact and are thus rarely noticed, some cause substantial damage to plants and the environment, and may have catastrophic effects on biodiversity. Box tree moth (Cydalima perspectalis Walker, 1859; Lepidoptera; Crambidae) is one of the most recent introductions to Europe [11] as well as to Croatia [12] causing serious damage to ornamental box (Buxus sp.) shrubs and trees.

Box tree moth was introduced to Europe in 2006 initially in Germany and Netherlands [13], and then it quickly spread to other European countries: Switzerland [14], England [15], France [16], Czech Republic [17], Italy [18], Slovakia [18], Austria [19], Slovenia [20], Hungary [21], Turkey [22], Romania [23] and Belgium [18]. The species is native to eastern Asia (India, China, Korea, Japan) [11] and feeds on every one of the most frequently planted box-tree species and varieties in Central Europe [24]. This rapid spread and establishment in European countries can be attributed to the ornamental plant trade as in particular box plants (Buxus sempervirens L.) are very popular ornamental garden plants. It is thought that the species was originally introduced with imports from China [11]. The larvae of the box tree moth are defoliating the plants posing a serious threat to these popular ornamentals especially in historical and formal gardens, hedging and topiary [11, 25].

The aim of this paper is to describe the biology of box tree moth with prognosis of its future spread and damages in Croatia.

\section{MATERIALS AND METHODS}

Young larvae (first and second instars) of box tree moth were collected in August and September 2013 in Arboretum Opeka, Vinica near Varaždin (coordinates N 46.327017; $E$ 16.14747) and adults were collected in Varaždin (N 46.31551, E 16.316509). They were brought to entomological laboratory, Croatian Forest Research Institute and reared to pupae and moths. All developmental stages were photographed with Olympus camera E30 and Olympus stereo microscope SZ X7 $(0,5 x)$. The adults were identified according to Mally and Nuss 2010 [26].

\section{RESULTS}

The box tree moth was recorded for the first time in North Croatia in August 2013 when larvae were found defoliating box plants (B. sempervirens) in Arboretum Opeka, Vinica (Figure 1). The larvae and moths were identified as C. prespectalis. According to

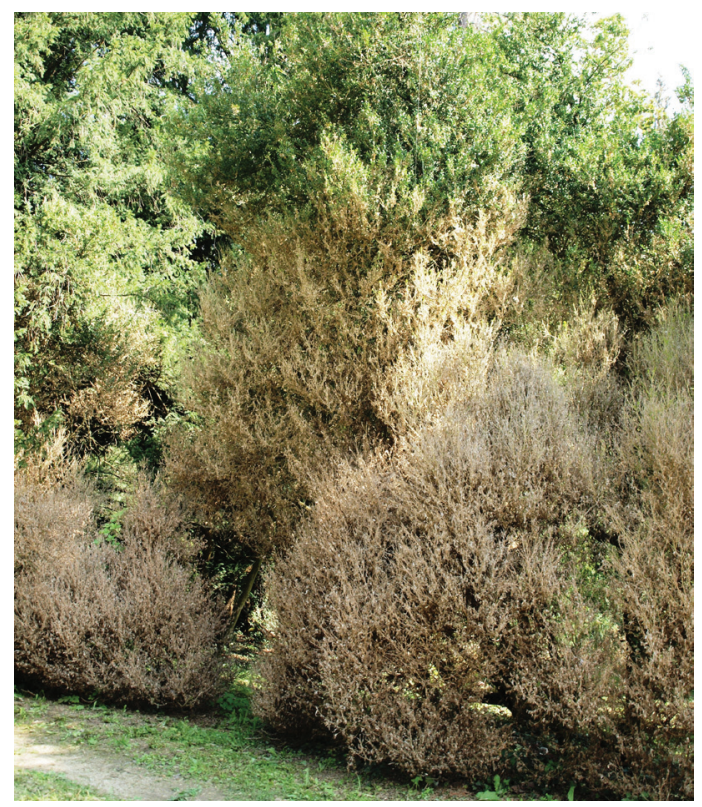

FIGURE 1. Defoliated box plants (Buxus sempervirens) in Arboretum Vinica, Croatia (25 September 2013) 
damages it can be assumed that the pest has been introduced to the region earlier (in 2011 or 2012) and that the primary infection has been undetected.

Newly hatched larvae were found on box trees (from eggs laid on the underside of box leaves), they are greenish yellow with black heads (Figure 2). Mature larvae have the green ground colour with a pattern of thick black and thin white stripes along the length of the body, with large black dots outlined in white on the dorsal side (Figure 3). They are

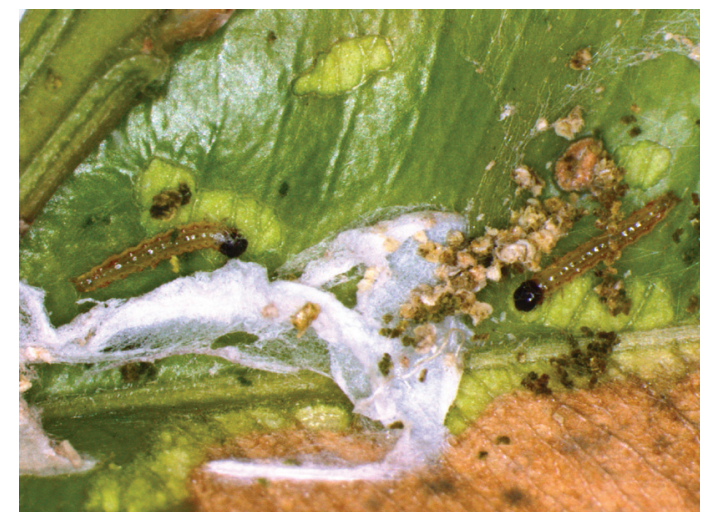

FIGURE 2. Newly hatched larvae, excrement and webbing of box tree moth (Cydalima perspectali) (26 September 2013)

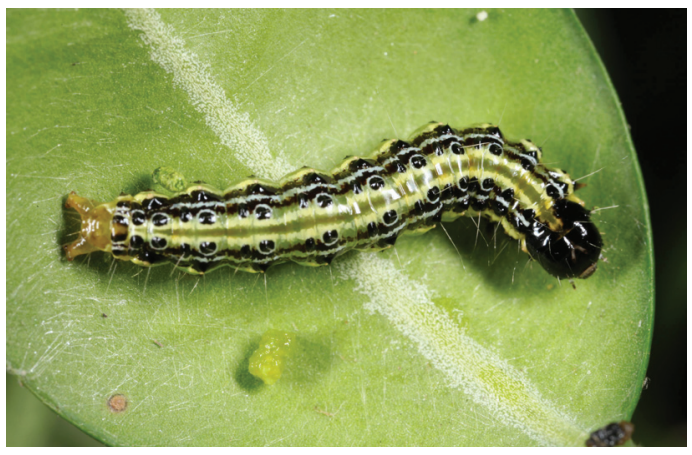

FIGURE 3. Mature larvae of box tree moth (photo György Csoka)

up to $4 \mathrm{~cm}$ in length, and have 6 larval stages.

The pupae are between 1.5 and $2.0 \mathrm{~cm}$ long. They are initially green with dark stripes on the dorsal surface, while older pupae turn brown. They are concealed in a cocoon of white

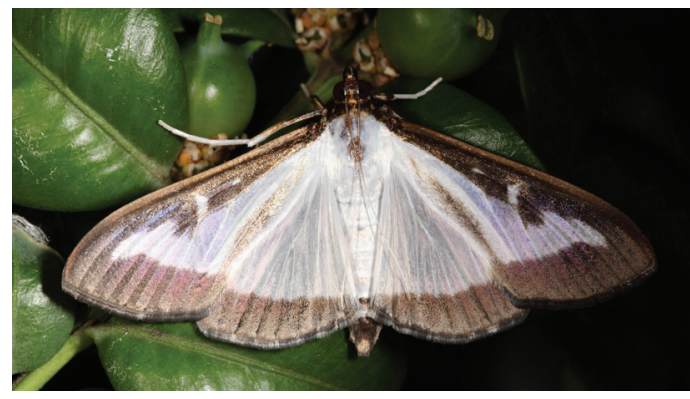

FIGURE 4. Adult of box tree moth (photo György Csoka)

webbing among the leaves and twigs of box trees.

Adults have a wingspan of around $4 \mathrm{~cm}$ with a thick dark brown border of uneven width around the edges of white-coloured wings (Figure 4). The moths are iridescent when looked from different angles. The body is white, with a dark brown head and posterior end of the abdomen.

During this research we could not define the exact number of generations as first damages were visible in August but at least two generations per year could be assumed in Croatia in 2013. The box tree moth has two to three generations per year in Europe, while in the native range up to 5 generations per year are possible [19]. It overwinters as larva, spinning a cocoon between box leaves in autumn and completing its development the following spring.

The damage caused on box tree plants at the locality of research was found to be serious. Young larvae feed in the lower surfaces of the leaves only and leave the upper epidermis intact, whereas older larval stages feed inside the webbing, leaving only the midribs intact (Figure 5), they also eat green bark of the young twigs. Younger larval instars feed sheltered between two spun leaves and later instars rest during the day in loosely spun webbing where they also overwinter. Webbing and larval excrement were found between leaves and twigs. After overwintering, the larvae continue feeding until the end of March and when fully grown, they pupate and the moths of first generation appear 


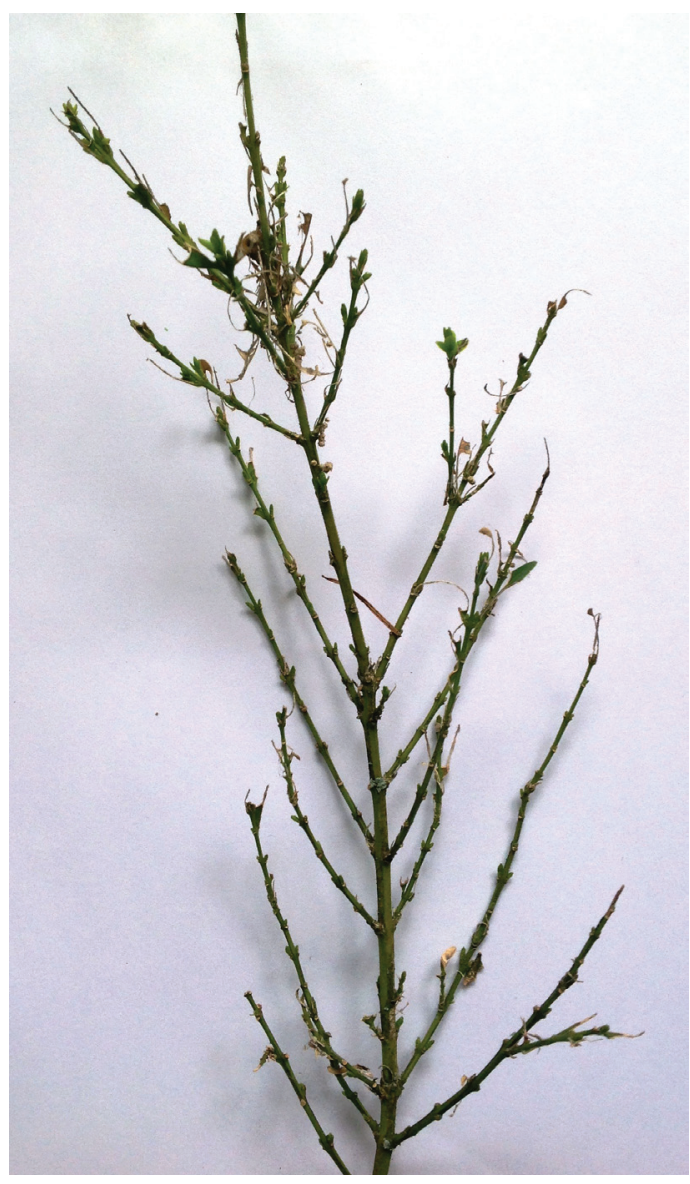

FIGURE 5. Total defoliation of box leaves, only midribs are left (September 2013)

[11]. The damaged box plants lose their amenity value as garden plant since defoliation is visible particularly on lower branches (Figure 1).

\section{DISCUSSION AND CONCLUSIONS}

Almost $90 \%$ of alien invertebrates in Europe were introduced unintentionally through human activities, mostly as contaminants of a commodity [27]. The main pathway of introduction of alien and invasive insect species on trees and shrubs is trade of ornamental plants [28]. In Europe, ornamental plant trade contributes significantly more than forestry products to the invasion of alien forest insects
[9]. More than $80 \%$ of alien insect species in Croatia ( $57 \%$ on agricultural lands and $28 \%$ in parks and gardens) have been established in man-made habitats [14]. Box tree moth is another invasive species introduced to Europe and Croatia with ornamental plants, establishing and quickly spreading in a new habitat [11]. Ornamental plants and flowers are transported also very rapidly around the globe allowing alien insects to survive during transport and established themselves in new environment. There is a strong suspicion that ornamental plants are one of main pathways of introduction of alien insects to Croatia due to the increase of the imported volumes from year to year [10]. Box tree hedges have an important value in historical gardens and are essential element of gardens and parks [14].

\section{Ways of spreading}

It is likely that the box tree moth reached Europe on horticultural box tree plants imported from China [11]. Eggs and small larvae are difficult to detect and are easily dispersed with contaminated plants. The box tree moth is a good flyer, so it can also disperse naturally (5 km/year) [18], with several generations per year and good flying abilities it has a relatively high self spread potential. It easily spreads from contaminated areas as its host plant is extensively traded all over Europe being one of the most popular and widely planted ornamental plants.

\section{Damage and control measures}

The defoliation reduces the amenity value and repeated severe defoliation can result in the death of plants [11]. First signs of box tree moth presence are the following:

- moths (from May/June and in August) and larvae (from March until October),

- first partially devoured leaf epidermis and later whole leaves and green bark eaten by larvae,

- webbing and light coloured excrements can be found between leaves and twigs The plants should be checked in the middle as box shrubs are usually very thick and 
when the infection starts the larvae live well protected inside the plants. If larvae, pupae or moths are found on box plants they cannot be misidentified for another species as this is the only one so far that makes such visible and characteristic damage. Ecological impact and damage may become particularly important when this pest reaches the main areas of natural distribution of Buxus spp. in Europe such as France, the Pyrenees, Montenegro and F.Y.R.O.M. where the European box tree is an essential component of unique forest ecosystems [11, 29].

Cultivated box trees can be protected by chemical insecticides or the ones based on Bacillus thuringiensis (Bt). In private gardens and on smaller plants, the moth may be controlled by hand picking caterpillars, by shaking trees or by spraying with water [19].

No natural enemies have been recorded in Europe so far [11] while it is neither attacked by predators (birds) because of the toxicity of the host plant [14]. Given all these circumstances this invasive pest has very favourable conditions (no natural enemies, favourable climate, widely available host plant) for spreading and establishing in new areas.

\section{Forecast of box tree moth spreading in Croatia}

Seven years after the first introduction, the pest has either naturally spread or been introduced multiple times and consequently it is now established widely across Europe [11].

This is the first record of this pest in Northern Croatia and, based on its potential, it can be expected that the pest will rapidly spread to other parts of Croatia damaging seriously box plants and thus becoming threat to gardens and parks in Croatia.

\section{Acknowledgement}

The author would like to thank Franjo Pavetic for the first information on the presence of the moth, Blaženka Ercegovac and Iva Franić for help in collecting and laboratory work, Marc Kenis for supplying valuable references, Dimitrios Avtzis and György Csóka for valuable comments on manuscript.

\section{REFERENCES}

1. KENIS M, RABITSCH W, AUGER-ROZENBERG M, ROQUES A 2007 How can alien species inventories and interception data help us prevent insect invasions? Bull Entomol Res 97 (5): 489-502. DOI: http://dx.doi.org/10.1017/S0007485307005184

2. LOCKWOOD J, HOOPES M, MARCHETTI M 2006 Invasion Ecology. Wiley-Blackwell, Hoboken, NJ, USA, $304 p$

3. DAVIS M A 2009 Invasion biology. Oxford University Press., Oxford, UK, $244 \mathrm{p}$

4. KENIS M, BRANCO M 2010 Impact of alien terrestrial arthropods in Europe. Chapter 5. In: Roques A, Kenis M, Lees D, Lopez-Vaa-monde C, Rabitsch W, Rasplus J-Y, Roy D (eds) Alien terrestrial arthropods of Europe. BioRisk 4 (1): 51-71. DOI: http://dx.doi.org/10.3897/biorisk.4.42

5. RASPLUS J-Y 2010 Future trends. Chapter 6. In: Roques A, Kenis M, Lees D, Lopez-Vaamonde
C, Rabitsch W, Rasplus J - Y, Roy D (eds) Alien terrestrial arthropods of Europe. BioRisk 4 (1): 7380. DOI: http://dx.doi.org/10.3897/biorisk.4.67

6. KENIS M, AUGER-ROZENBERG M-A, ROQUES A, TIMMS L, PÉRÉ C, COCK M J W, SETTELE J, AUGUSTIN S, LOPEZ-VAAMONDE C 2009 Ecological effects of invasive alien insects. Biol Invasions 11 (1): 21-45. DOI: http://dx.doi.org/10.1007/978-14020-9680-8 3

7. NENTWIG W 2007 Biological Invasions. SpringerVerlag Berlin, Heidelberg, 441 p. DOI: http:// dx.doi.org/10.1007/978-3-540-36920-2

8. MATTSON W, VANHANEN H, VETELI T, SIVONEN S, NIEMELÄ P 2007 Few immigrant phytophagous insects on woody plants in Europe: legacy of the European crucible? Biol Invasions 9 (8): 957974. DOI: http://dx.doi.org/10.1007/s10530-0079096-y 
9. ROQUES A 2010 Alien forest insects in a warmer world and a globalised economy: impacts of changes in trade, tourism and climate on forest biosecurity. New Zeal J For Sci 40 Suppl: 77-94

10. MATOŠEVIĆ D, PAJAČ ŽIVKOVIĆ I 2013 Alien phytophagous insect and mite species on woody plants in Croatia (in Croatian with English summary). Sumar list 137 (3-4): 191-203

11. NACAMBO S, LEUTHARDT $F$ L G, KENIS M 2013 Development characteristics of the box-tree moth Cydalima perspectalis and its potential distribution in Europe. J Appl Entomol 138 (1-2): 14-26. DOI: http://dx.doi.org/10.1111/jen.12078

12. KOREN T, ČRNE M 2012 The first record of the box tree moth, Cydalima perspectalis (Walker, 1859) (Lepidoptera, Crambidae) in Croatia. Nat Croat 21 (2): 507-510

13. KRÜGER E O 2008 Glyphodes perspectalis (Walker, 1859) - new for the European fauna (Lepidoptera: Crambidae) (in German with English summary). Entomologische Zeitschrift mit Insekten-Börse 118 (2): 81-83

14. LEUTHARDT $F \quad L$ G, BILLEN W, BAUR B 2010 Spread of the box-tree pyralid Diaphania perspectalis (Lepidoptera: Pyralidae) in the region of Basel - a pest species new for Switzerland. (in German with English summary). Entomo Helvetica 3: 51-57

15. SALISBURY A, KORYCINSKA A, HALSTEAD A J 2012 The first occurrence of larvae of the box tree moth, Cydalima pesrpectalis (Lepidoptera: Crambidae) in private gardens in the UK. $\mathrm{Br} J$ Entomol Nat Hist 25: 1-5

16. FELDTRAUER J F, FELDTRAUER J J, BRUA C 2009 Premiers signalements en France de la Pyrale du Buis Diaphania perspectalis (Walker, 1859), espece exotique envahissantes'attaquant aux Buis (Lepidoptera, Crambidae). Bull Soc Ent Mulhouse 65 (4): 55-58

17. SUMPICH J 2011 Motýli Národních park Podyjí a Thayatal. Správa Národního parku Podyjí, Znojmo.

18. BESTIMMUNGSHILFE DES LEPIFORUMS: Cydalima perspectalis . URL: http://www.lepiforum.de/ lepiwiki.pl?Cydalima_Perspectalis (25 September 2013)

19. PERNY B 2010 Mass outbreak of box tree pyralid Diaphania perspectabitis in the East of Austria (in German with English summary). Forstschutz aktuell 50: 17-19

20. SELAK G 2012 Six new alien phytophagous insect species recorded in Slovenia in 2011. Acta Entomol Sloven 20: 31-44
21. SÁFIÁNSZ, HORVÁTHB2011 Boxtreemoth (Cydalima perspectalis (Walker, 1859)) - a potential garden pest - new member in the Hungarian lepidoptera fauna (Lepidoptera: Crambidae) (in Hungarian with English summary). Növényvédelem 47 (10): 437438

22. HIZAL E, KOSE M, YESIL C, KAYNAR D 2012 The new pest Cydalima perspectalis (Walker, 1859) (Lepidoptera: Crambidae) in Turkey. J Anim Vet Adv 11 (3): 400-403. DOI: http://dx.doi. org/10.3923/javaa.2012.400.403

23. SZEKELY L, DINCA V, MIHAI C 2011 Cydalima perspectalis (Walker, 1859), a new species for the Romanian fauna (Lepidoptera: Crambidae: Spilomelinae). Bul Inf Entomol 22 (3-4): 73-77

24. LEUTHARDT F L G, BAUR B 2013 Oviposition preference and larval development of the invasive moth Cydalima perspectalis on five European boxtree varieties. J Appl Entomol 137 (6): 437-44. DOI: http://dx.doi.org/10.1111/jen.12013

25. SIGG C R 2009 Auch das noch: Ein neuer BuchsSchädling schlägt zu. Der Gartenbau (Solothurn) (4): 2-4

26. MALLY R, NUSS M 2010 Phylogeny and nomenclature of the box tree moth, Cydalima perspectalis (Walker, 1859) comb. n., which was recently introduced into Europe (Lepidoptera: Pyraloidea: Crambidae: Spilomelinae). Eur J Entomol 107 (3): 393-400

27. ROQUES A, RABITSCH W, RASPLUS J -Y, LOPEZVAAMONDE C, NENTWIG W, KENIS M 2009 Alien Terrestrial Invertebrates of Europe. In: Drake J A (ed) DAISIE, Handbook of Alien Species in Europe, Springer Science + Business Media B V, netherlands, pp 63-79. DOI: http://dx.doi.org/10.1007/978-14020-8280-1

28. ROQUES A 2008 The pan-European inven-tory of alien species established on trees on shrubs, a tool for predicting taxa and ecosystems at risk-final results of the DAI-SIE project (presentation). In: Alien invasive species and in-ternational trade, 2nd meeting of IUFRO Working Unit 7.03.12, National Conservation Training Center, Shepherdstown, WV, USA, 26-30 May 2008. URL: http://www. forestry.gov.uk/pdf/IUFRO Shepherdstown Roques Sheperdstown end.pdf/\$FILE/IUFRO Shepherdstown_Roques_Sheperdstown_end.pdf

29. ŠILIĆ Č 1983 Tree and Shrub Atlas (in Bosnian). Svjetlost, Sarajevo, Bosnia and Herzegovina $217 p$ 